\title{
PENGARUH JARAK TERHADAP PERSEPSI SEHAT PENGHUNI PERUMAHAN KECAMATAN TEBET JAKARTA SELATAN
}

\section{The Effect of Distance on Health \\ Perceptions of Housing \\ Residents in Tebet Sub-distric \\ South Jakarta}

\author{
Mohammad Aditya Ajie Wicaksono \\ Program Studi Perencanaan Wilayah dan \\ Kota, Universitas Trisakti \\ Email: adityaaji69@gmail.com
}

\section{Nur Intan Simangunsong \\ Program Studi Arsitektur Lanskap, Universitas Trisakti}

Email: nurintan@trisakti.ac.id

\section{Benny Benyamin Suharto}

Program Studi Perencanaan Wilayah dan Kota, Universitas Trisakti

\section{ABSTRACT}

The poor environmental conditions in Jakarta indicate that housing residents are not healthy, therefor the need for green open spaces that are close to housing is very important. The purpose of this study is to determine the effect of green open space on the health perceptions of housing residents. The research method used is descriptive quantitative with primary data collection stages; limiting the distance of the research location area within a radius of 1-3 $\mathrm{km}$; perform multiple linear regression analysis and cross-tabulation. The results of this study indicate that the negative coefficient is not unidirectional; the adolescent and elderly age group had a good healthy perception, reaches 42.7\%; male gender showed a good healthy perception 35.4\%; Housing residents who do not work have a healthy perception of $33.3 \%$. The perception of health decreases with increasing distance and is increasingly visible in residents who live within 1-3 km of green open space. This research serves as input to related agencies that the minimum distance of green open space to housing is 300-1000 $\mathrm{m}$ because it is important to provide good health effects for housing residents.

Keywords: distance, green open space, health perception, housing resident

\section{PENDAHULUAN}

Proses urbanisasi dan alih fungsi lahan terhubung dengan berbagai tantangan negatif (kebisingan, polusi udara, dan penurunan ruang hijau) (Kabisch et al. 2015) untuk pembangunan kota yang berkelanjutan di berbagai kota. Kelangkaan lahan yang disebabkan oleh bertambahnya jumlah penduduk di kawasan perkotaan (Kusumadewi. 2014) menimbulkan permasalahan baru bagi penghuni perumahan yang berdampak pada penurunan kualitas lingkungan, kuantitas ruang terbuka hijau dan penurunan kualitas kesehatan penghuni perumahan.

Jarak ruang terbuka hijau memberikan pengaruh yang signifikan terhadap persepsi sehat penghuni perumahan (Maas et al. 2006; Suminah et al. 2017). Ruang terbuka hijau (RTH) memiliki fungsi ekologis seperti mengendalikan iklim mikro, memurnikan dan menjaring udara dari debu, polutan, mengurangi kebisingan, dan getaran (Lee et al. 2010). Ruang terbuka hijau di DKI Jakarta baru mencapai 9.9\% dari target 30\% (Dinas Pertamanan DKI Jakarta, 2019) yang sudah diamanatkan undang-undang dasar Penataan Ruang No.5 Tahun 2008. Berdasarkan data Pemerintah Daerah DKI Jakarta tahun 2017, jumlah RTH di DKI Jakarta sudah mencapai angka 3.131 buah, dikarenakan banyaknya perubahan penggunaan lahan di DKI Jakarta. Berdasarkan data BPS tahun 2019, Kota Jakarta Selatan memiliki luas 141,27 km² dan memiliki 10 kecamatan dan 65 kelurahan yang dihuni oleh penduduk sebesar 2.264,7 ribu dengan laju pertumbuhan penduduk $0.87 \%$ pada tahun 2018 dengan kepadatan penduduk $15.900 \mathrm{~km}^{2}$. Kecamatan Tebet merupakan kecamatan terpadat dengan total kepadatan penduduk 23.419 jiwa/ km² $^{2}$. Kota Jakarta Selatan memiliki luas RTH terluas kedua setelah Jakarta Pusat. Total luas RTH di Jakarta Selatan sebesar 1.931,065 ha.

Dengan sedikitnya RTH mengindikasikan kesehatan masyarakat menurun (Kusumadewi, 2014). Pentingnya RTH yang berkualitas baik, harus tersedia di dekat perumahan sebagai kawasan yang memberikan fungsi ekologis yang dapat menghilangkan kesenjangan kesehatan manusia (Lee et al. 2010). Kecamatan Tebet memiliki jumlah penduduk yang paling tinggi dengan luasan RTH paling sedikit yaitu hanya 5\% dari total keseluruhan luas RTH di Jakarta Selatan. Dengan demikian pertanyaan penelitian ini adalah faktor apa yang mempengaruhi persepsi sehat penghuni perumahan terhadap RTH di Kecamatan Tebet?

Adapun yang menjadi ruang lingkup pada penelitian ini adalah RTH yang berada di sekitar kawasan perumahan di Kecamatan Tebet, Jakarta Selatan yang dapat dilihat pada Gambar 1.

Tujuan dilakukannya penelitian ini untuk mengetahui pengaruh RTH terhadap persepsi sehat penghuni perumahan. Sasaran dari penelitian ini adalah teridentifikasinya persepsi sehat penghuni perumahan berdasarkan jarak RTH dan terindentifikasinya persepsi sehat penghuni perumahan berdasarkan karakteristik sosial demografi.

\section{STUDI PUSTAKA}

\section{Definisi Ruang Terbuka Hijau (RTH)}

Berlandaskan Peraturan Menteri Pekerjaan Umum No.5 Tahun 2008 Tentang Pedoman Penyediaan Dan Pemanfaatan Ruang Terbuka Hijau Di Kawasan Perkotaan mendefinisikan ruang terbuka dalam kota atau wilayah yang lebih luas berbentuk area/ kawasan maupun memanjang/jalur dimana penggunaannya lebih bersifat terbuka yang pada dasarnya tanpa bangunan. Ruang Terbuka Hijau Kawasan Perkotaan (RTHKP) menurut Peraturan Menteri Dalam Negeri No. 1 Tahun 2007 tentang Penataan Ruang Terbuka Hijau Kawasan Perkotaan diartikan sebagai bagian dari ruang terbuka suatu kawasan perkotaan yang diisi oleh tanaman guna mendukung manfaat ekologi, sosial, budaya, ekonomi dan estetika. 


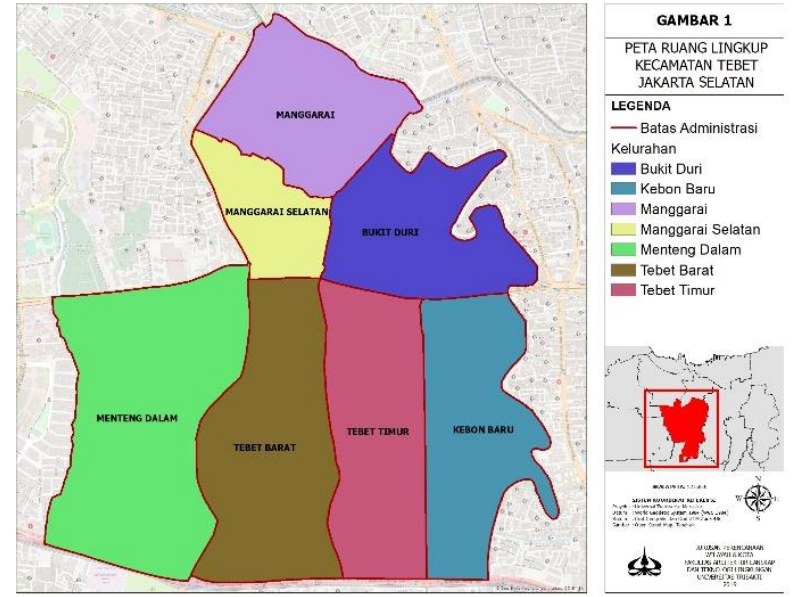

Gambar 1. Peta Ruang Lingkup Penelitian Kecamatan Tebet Jakarta Selatan.

\section{Klasifikasi Ruang Terbuka Hijau (RTH)}

Berlandaskan Peraturan Menteri Pekerjaan Umum No.5 Tahun 2008 Tentang Pedoman Penyediaan Dan Pemanfaatan Ruang Terbuka Hijau di Kawasan Perkotaan. Penyediaan ruang terbuka hijau di perumahan terbagi menjadi dua, yakni RTH pekarangan merupakan RTH privat yang berada pada pekarangan rumah penghuni, sedangkan RTH lingkungan merupakan RTH publik skala lingkungan permukiman yang dapat digunakan oleh seluruh penghuni. Adapun dalam pedoman Kementerian PU, skala pelayanan RTH terbagi menjadi 5 yaitu, tingkat Kota, Kecamatan, Kelurahan, RW, dan RT yang disesuaikan dengan jumlah penduduk, luas minimal, dan jenis tanaman. Adapun pemanfaatan RTH lingkungan harus memiliki fungsi sosial yang dapat menjadi tempat untuk melakukan aktivitas, bersosialisasi, dan alternatif rekreasi bagi masyarakat (Jessica et al. 2019).

Berdasarkan Undang-undang penataan ruang pada intinya menjelaskan bahwa yang dimaksud dengan RTH terdiri dari ruang terbuka hijau publik dan ruang terbuka hijau privat, yakni sebagai berikut:

- RTH Publik merupakan RTH yang dimiliki dan dikelola oleh pemda yang digunakan untuk kepentingan masyarakat umum. yang termasuk RTH publik adalah, Taman Kota; Taman Pemakaman Umum; Jalur Hijau.

- RTH Privat berupa kebun atau halaman rumah/gedung yang ditanami oleh tumbuhan dan merupakan milik masyarakat/swasta.

\section{Luas Ruang Terbuka Hijau (RTH)}

Luas RTH yang besar dengan distribusi yang merata serta memiliki vegetasi alami mampu meningkatkan aksesibilitas masyarakat dan efek pemulihan seseorang. (Ekkel et al. 2017) Jarak dan waktu menjadi penting karena dengan jarak yang dekat serta waktu yang singkat akan meningkatkan kemungkinan akses yang lebih mudah serta minim halangan untuk menuju RTH (Kusumadewi, 2014). Ruang terbuka hijau yang lebih luas lebih berpengaruh dibandingkan yang terdekat (Nutsford et al. 2013). Luasan RTH dengan ukuran paling minimum 1 ha yang diproses menggunakan ArcGIS, menghasilkan nilai positif antara akses dengan kesehatan. Namun, sulit jika bukan tidak mungkin bahwa ukuran minimum selain 1 ha akan akan menghasilkan keterkaitan yang lebih lemah atau lebih kuat atau bahkan tidak ada kaitan sama sekali.
(Nutsford et al. 2013) Pemilihan RTH dengan luas 1 ha diharapkan dapat mempengaruhi persepsi sehat penghuni perumahan di Kecamatan Tebet ini.

\section{Jarak Ruang Terbuka Hijau (RTH)}

Jarak menjadi faktor penting dalam keterkaitan antara ruang hijau dan kesehatan (Maas et al. 2006). Sebuah Badan Pemerintah Inggris, English Nature merekomendasikan bahwa seseorang yang tinggal di kota harus memiliki ruang terbuka hijau yang dapat di akses, kurang dari $300 \mathrm{~m}$ dari rumah. European Environment Agency (EEA) merekomendasikan bahwa orang harus memiliki akses ke ruang hijau dalam jarak 15 menit berjalan kaki. Sebuah studi di Denmark menunjukkan, orang-orang yang tinggal lebih dari $1 \mathrm{~km}$ dari ruang hijau menghasilkan 1,42 peluang mengalami stres lebih tinggi daripada mereka yang tinggal kurang dari 300-1000 m dari ruang hijau terdekat memiliki skor kesehatan yang sebanding dengan responden yang tinggal kurang dari $300 \mathrm{~m}$ dari ruang hijau, menunjukkan bahwa ruang hijau pada jarak di luar $300 \mathrm{~m}$ memengaruhi kesehatan secara positif juga. Lebih jauh lagi, persentase RTH di sekitar tempat tinggal pada radius atau jarak $1-3 \mathrm{~km}$ berhubungan dengan kondisi kesehatan seseorang (Stigsdotter et al. 2010). Kondisi kesehatan orang tersebut pada jarak yang lebih dari $1 \mathrm{~km}$ semakin menurun. Jarak yang dekat serta waktu yang singkat akan meningkatkan kemungkinan akses yang lebih mudah serta minim halangan (Maas et al. 2006). Penerapan ruang terbuka hijau seharusnya berada di tengah-tengah wilayah sehingga semua warga dapat mencapainya dengan mudah dan cepat.

\section{Persepsi Sehat}

Persepsi sehat sebagai proses pemberian arti terhadap lingkungan oleh individu (Kusumadewi, 2014). World Health Organization (WHO) memberikan definisi kesehatan yang diberlakukan di seluruh dunia. Definisi kesehatan dari WHO ini diadopsi dari berbagai ilmu dan bidang pengetahuan. Konsep kesehatan dari WHO memiliki dimensi bio-psiko-sosial. Sehat dikatakan sebagai kondisi sejahtera dari bio-psiko-sosial. persepsi sehat merupakan penilaian diri yang bersifat sangat subjektif berdasarkan status kesehatan menurut individu masing-masing. Penilaian diri kesehatan secara jelas mengukur sesuatu yang lebih dan sesuatu yang kurang apabila dibandingkan dengan penilaian medis secara objektif (Kusumadewi, 2014).

\section{Determinan Persepsi Sehat}

Lama tinggal seseorang (12 bulan) dapat mempengaruhi kondisi kesehatan dikarenakan perlunya waktu bagi ruang hijau untuk memberikan efek pada seseorang (Maas et al. 2006). Dalam penelitian ini terdapat tiga faktor yang mempengaruhi persepsi sehat penghuni perumahan, yaitu ialah:

1. Usia, hubungan umur dengan persepsi sehat merupakan hubungan yang cukup kompleks. Hal ini disebabkan oleh konsep persepsi sehat yang menekankan subyektivitas seseorang. Hal ini mempengaruhi semua golongan usia yang berbeda mendapatkan manfaat yang signifikan dari RTH (Kusumadewi, 2014).

2. Jenis kelamin, terdapat kesenjangan persepsi sehat dengan risiko kematian berdasarkan jenis kelamin. Perempuan lebih sering melaporkan kondisi kesehatan 
yang lebih buruk dibanding laki-laki (Kusumadewi, 2014).

3. Pekerjaan, terdapat hubungan yang signifikan status pekerjaan dengan persepsi sehat yang dilaporkan sendiri (Kusumadewi, 2014).

\section{METODE PENELITIAN}

Metode penelitian yang digunakan adalah pendekatan deskriptif kuantitatif. Hal yang dilakukan adalah mengidentifikasi pengaruh jarak RTH terhadap persepsi sehat penghuni perumahan. Jarak RTH ini berkaitan dengan persepsi sehat penghuni. berdasarkan hal tersebut, variabel yang perlu diperhatikan dalam mengidentifikasi pengaruh jarak terhadap persepsi sehat penghuni perumahan disajikan pada Tabel 1 .

Tabel 1. Variabel Penelitian

\begin{tabular}{lcc}
\hline \multicolumn{1}{c}{ Variabel } & Skala Data & Sumber Data \\
\hline Jarak & Interval & Angket \\
Usia & Interval & Angket \\
Jenis Kelamin & Nominal & Angket \\
Pekerjaan & Nominal & Angket \\
Persepsi Sehat & Interval & Angket \\
\hline
\end{tabular}

Pemilihan lokasi Kecamatan Tebet berdasarkan data Badan Pusat Statistik (BPS) yang memiliki kepadatan penduduk tertinggi di Jakarta Selatan dan memiliki luas RTH berdasarkan data Kementerian Agraria dan Tata Ruang, sekitar 5\% dari total seluruh kecamatan di Jakarta Selatan. Kecamatan Tebet memiliki berbagai macam dan jenis RTH dengan luasan yang berbeda disetiap Kelurahannya. Dari sekian banyak RTH di Kecamatan Tebet, RTH yang memiliki vegetasi pepohonan yang rindang di dalamnya, bukan hanya rerumputan, dan lapangan olahraga dan yang menjadi faktor penentu untuk menjadi lokasi penelitian adalah luas dari RTH tersebut. Persebaran RTH dan penghuni perumahan pada Kecamatan Tebet, Jakarta Selatan dapat dilihat dengan jelas pada Gambar 2.
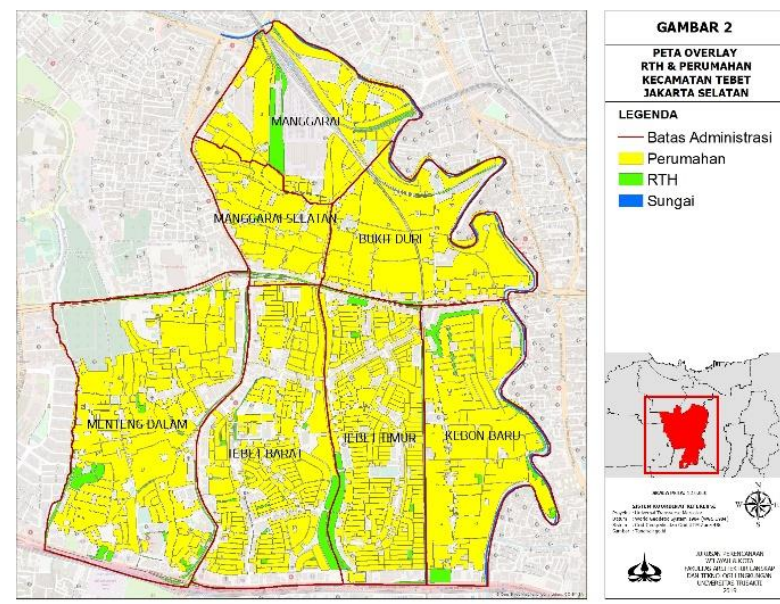

Gambar 2. Peta Overlay RTH dan Perumahan Kecamatan Tebet Jakarta Selatan.

Taman Honda dirasa mampu memberikan manfaat bagi lingkungan sekitarnya yang didukung dari luasan dan fungsi ekologis seperti kerindangan pepohonannya, serta memiliki fungsi sosial dan psikologikal (rekreasi dan kesehatan) yang berdampak pada lingkungan di sekitar. Populasi pada penelitian ini adalah pengguna atau pengunjung RTH Taman Honda yang merupakan penghuni perumahan yang tinggal pada jarak antara 300$1.000 \mathrm{~m}$ dari Taman Honda. Adapun batasan wilayah dalam penelitian ini adalah administrasi Kecamatan Tebet, jarak dengan batasan $3 \mathrm{~km}$ dari Taman Honda, jalan tol di arah selatan, untuk lebih jelasnya dapat dilihat pada Gambar 3.

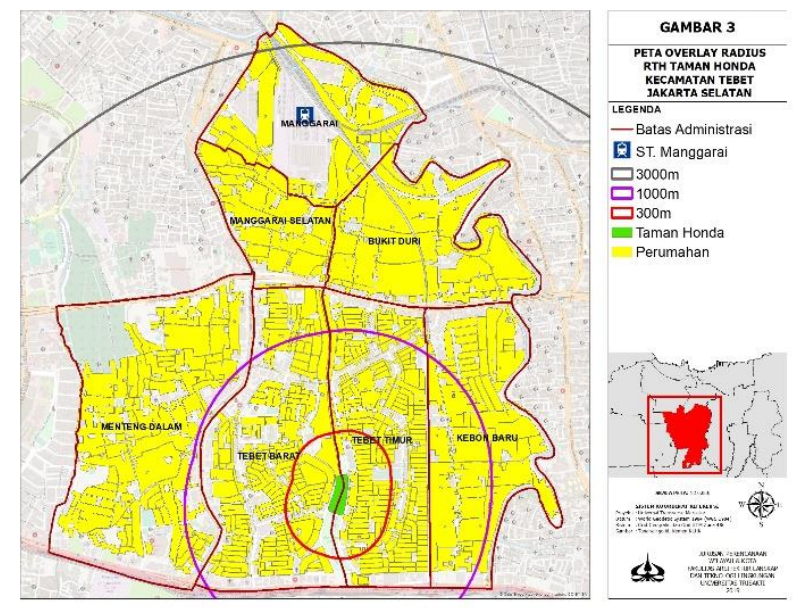

Gambar 3. Peta Overlay Radius RTH Taman Honda Kecamatan Tebet Jakarta Selatan.

Populasi pada penelitian ini adalah pengguna atau pengunjung RTH Taman Honda yang merupakan penghuni perumahan yang tinggal pada jarak $<300 \mathrm{~m}$ $1000 \mathrm{~m}$ dari Taman Honda. Adapun batasan dalam penelitian ini adalah administrasi Kecamatan Tebet, jarak dengan batasan $3 \mathrm{~km}$ dari objek penelitian, jalan tol di arah selatan, dan RTH yang menjadi fokus dalam objek penelitian ini sendiri yakni Taman Honda.

Penentuan sampel penelitian ini adalah populasi (dalam hal ini adalah penghuni perumahan, baik laki-laki ataupun perempuan) yang bersedia mengisi formulir angket. Dalam menilai persepsi sehat penghuni perumahan, dilakukan perhitungan berdasarkan rumus Lemeshow et al. (1990) sebagai berikut:

$$
n=\frac{Z_{1-\frac{a}{2} * p(1-p)}^{2}}{d^{2}}
$$

\begin{tabular}{lll}
\multicolumn{2}{l}{ Keterangan } & \\
$\mathrm{n}$ & $:$ & Jumlah sampel \\
$\mathrm{Z}^{2} .1-\mathrm{a} / 2$ & $:$ & $\begin{array}{l}\text { Nilai standar dari distribusi sesuai nilai } \\
\mathrm{a}=5 \%=1.96\end{array}$ \\
$\mathrm{~d}$ & $: \begin{array}{l}\text { simpangan mutlak } \\
\text { kesalahan } 10 \%(0.10)\end{array}$ \\
$\mathrm{P}$ & $: \quad \begin{array}{l}\text { Proporsi populasi } \\
\mathrm{P}\end{array}$
\end{tabular}

Untuk menghitung besar sampel minimum diperlukan nilai proporsi yang diambil dari penelitian sebelumnya (Kusumadewi, 2014) menggunakan asumsi sebanyak 50\% $(\mathrm{p}=0,5)$. Kemudian, tingkat kepercayaan yang digunakan adalah 95\% dengan tingkat kesalahan 10\% (0.10). Dengan demikian, jumlah sampel minimal yang diperoleh berdasarkan rumus tersebut ialah sebagai berikut: 


$$
n=\frac{(1,96)_{* 0.5(1-0,5)}^{2}}{(0,10)^{2}}=96 \text { responden }
$$

Berdasarkan perhitungan di atas, jumlah sampel yang diharuskan adalah minimal sebanyak 96 responden. Unit analisis dalam penelitian ini mencakup penghuni perumahan yang mengunjungi RTH Taman Honda di Kecamatan Tebet, Kota Jakarta Selatan. Pengambilan sampel dalam penelitian ini dilakukan secara random sampling dengan menggunakan orientasi kunjungan.

Pengolahan data dilakukan dengan menggunakan Skala Likert untuk mengukur sikap, preferensi maupun persepsi seseorang tentang suatu fenomena yang terjadi. Skala Likert ini terdiri atas lima pilihan skala, yaitu Sangat Setuju (SS), Setuju (SS), Biasa Saja atau Netral (N), Tidak Setuju (TS), dan Sangat Tidak Setuju (STS). Setelah data dikumpulkan, kemudian dilakukan uji statistik berupa uji validitas dan uji reabilitas kuesioner untuk mengetahui validitas data dan kemudian hasil dari skala likert yang telah diperoleh disusun dalam bentuk distribusi frekuensi. Distribusi frekuensi merupakan susunan data menurut interval atau kategori tertentu dalam sebuah daftar. Dalam menyusun distribusi frekuensi terdiri beberapa langkah, yang diantaranya adalah:

1. Menentukan jumlah kelas interval. Pada penelitian ini jumlah kelas terbagi menjadi dua, yaitu kelas Tinggi (2), dan Rendah (1).

2. Menentukan rentang data (range). Dalam menentukan rentang data dapat dilihat pada rumus berikut:

$$
\text { Rentang Data }=\text { Skor Maksimum }- \text { Skor Minimum }
$$

3. Menentukan panjang kelas interval.

$$
\text { Panjang Kelas Interval }=\frac{\text { Rentang Data }}{\text { Jumlah Kelas Interval }}
$$

Data dianalisis menggunakan analisis regresi linear berganda untuk mengetahui arah hubungan antara variabel bebas dengan variabel terikat. Analisis ini digunakan untuk mengetahui hubungan positif atau negatif dari variabel bebas dan untuk memprediksikan nilai dari variabel terikat serta menentukan kejadian kenaikan atau penurunan dari variabel bebas. Adapun rumus dari analisis regresi linier berganda adalah sebagai berikut:

$$
Y=a+\beta x+\ldots+e
$$

Keterangan:

Y : Variabel Terikat

$X$ : Variabel Bebas

$a:$ konstanta atau intercept

$\beta$ : angka arah atau slope

e : residual regresi atau error

Setelah dilakukan analisis regresi linear berganda, kemudian dilakukan analisis lanjutan untuk mengetahui hubungan antar variabel melalui tabulasi silang (crosstab). Analisis tabulasi silang (crosstab) dilakukan untuk mendukung hasil dari analisis regresi linear berganda dan untuk melihat kedalaman atau tanggapan penghuni perumahan mengenai persepsi sehat itu sendiri.

\section{HASIL DAN PEMBAHASAN}

Berdasarkan hasil analisis dengan menggunakan regresi linear berganda, ditemukan bahwa arah hubungan seluruh variabel negatif. Hal ini disajikan pada Tabel 2, berikut ini.

Tabel 2. Hasil Analisis Regresi Linear Berganda

\begin{tabular}{lcc}
\hline Variabel & Koefisien beta & Sig \\
\hline Konstanta & 78.250 & 0.00 \\
Jarak $(\mathrm{J})$ & -5.397 & 0.00 \\
Usia $(\mathrm{U})$ & -1.910 & 0.03 \\
Jenis Kelamin $(\mathrm{JK})$ & -5.849 & 0.00 \\
Pekerjaan $(\mathrm{P})$ & -6.463 & 0.00 \\
\hline
\end{tabular}

Dapat dilihat pada Tabel 2 bahwa variabel jarak, usia, jenis kelamin, pekerjaan memiliki pengaruh signifikan nilai sig $<0.05$ dengan nilai koefisien negatif pada persepsi sehat penghuni perumahan Kecamatan Tebet secara signifikan dengan model:

$$
y=78,250-5,397 \mathrm{~J}-1,910 \mathrm{U}-5,849 \mathrm{JK}-6,46{ }_{3} \mathrm{P}
$$

\section{Jarak Ruang Terbuka Hijau (RTH) terhadap Persepsi Sehat}

Berdasarkan Tabel 2 di atas jarak memiliki nilai koefisien negatif $(-5,397)$, artinya jika variabel bebas lain nilainya tetap dan jarak mengalami kenaikan $1 \%$, maka persepsi sehat (Y) akan mengalami penurunan sebesar 5,397. Koefisien bernilai negatif artinya terjadi hubungan negatif antara jarak dengan persepsi sehat. Semakin tinggi jarak maka semakin turun persepsi sehat penghuni perumahan. Untuk melihat hubungan antara jarak dan persepsi sehat maka dilakukan analisis tabulasi silang yang dapat dilihat pada Tabel 3, berikut ini.

Tabel 3. Analisis Tabulasi Silang Jarak dan Persepsi Sehat

\begin{tabular}{lcc}
\hline Jarak Penghuni & \multicolumn{2}{c}{ Persepsi Sehat } \\
\cline { 2 - 3 } Perumahan & Baik & Buruk \\
\hline$>300 \mathrm{~m}$ & $\mathbf{1 9 . 8}$ & 4.2 \\
$300 \mathrm{~m}-1000 \mathrm{~m}$ & 19.8 & 21.9 \\
$1 \mathrm{~km}-3 \mathrm{~km}$ & 11.5 & $\mathbf{2 2 . 9}$ \\
\hline
\end{tabular}

Berdasarkan tabel di atas dapat dilihat bahwa 19 orang yang tinggal pada jarak $>300 \mathrm{~m}$ dari Taman Honda memiliki persepsi sehat yang baik; terdapat variasi pada jarak 300-1000 m yaitu sebanyak 19 orang penghuni perumahan memiliki persepsi sehat baik, serta sebanyak 21 orang penghuni perumahan memiliki persepsi sehat yang buruk dan pada jarak 1-3 km sebanyak 21 orang penghuni perumahan memiliki persepsi sehat yang buruk. Tingkat persepsi sehat penghuni perumahan akan semakin menurun seiring bertambahnya jarak tempat tinggal mereka hingga pada jarak 1-3 km dari Taman Honda. Jarak memiliki tingkat hubungan yang kuat dengan persepsi sehat. Hal penting terkait dengan persepsi sehat penghuni perumahan, bahwa semakin dekat jarak tempat tinggal seseorang dengan Taman Honda, maka semakin baik pula persepsi sehat yang 
dirasakan penghuni ketika mereka mengunjungi Taman Honda, persepsi sehat ini semakin menurun seiring bertambahnya jarak tempat tinggal penghuni perumahan dari Taman Honda. Maka peletakan RTH sebagai kawasan yang memberikan fungsi ekologis sebaiknya dekat dengan perumahan sehingga dapat dirasakan oleh penghuni perumahan, untuk lebih jelasnya dapat dilihat pada Gambar 4, berikut ini.
Jenis kelamin memiliki nilai yang signifikan nyata $(0.00)$ yang berarti jenis kelamin memiliki pengaruh terhadap persepsi sehat penghuni perumahan. Jenis kelamin memiliki nilai koefisien negatif sebesar $(-5.849)$, artinya terdapat hubungan negatif antara jenis kelamin dengan persepsi sehat. Dapat disimpulkan bahwa perempuan memiliki nilai persepsi sehat lebih rendah dibandingkan dengan laki-laki.
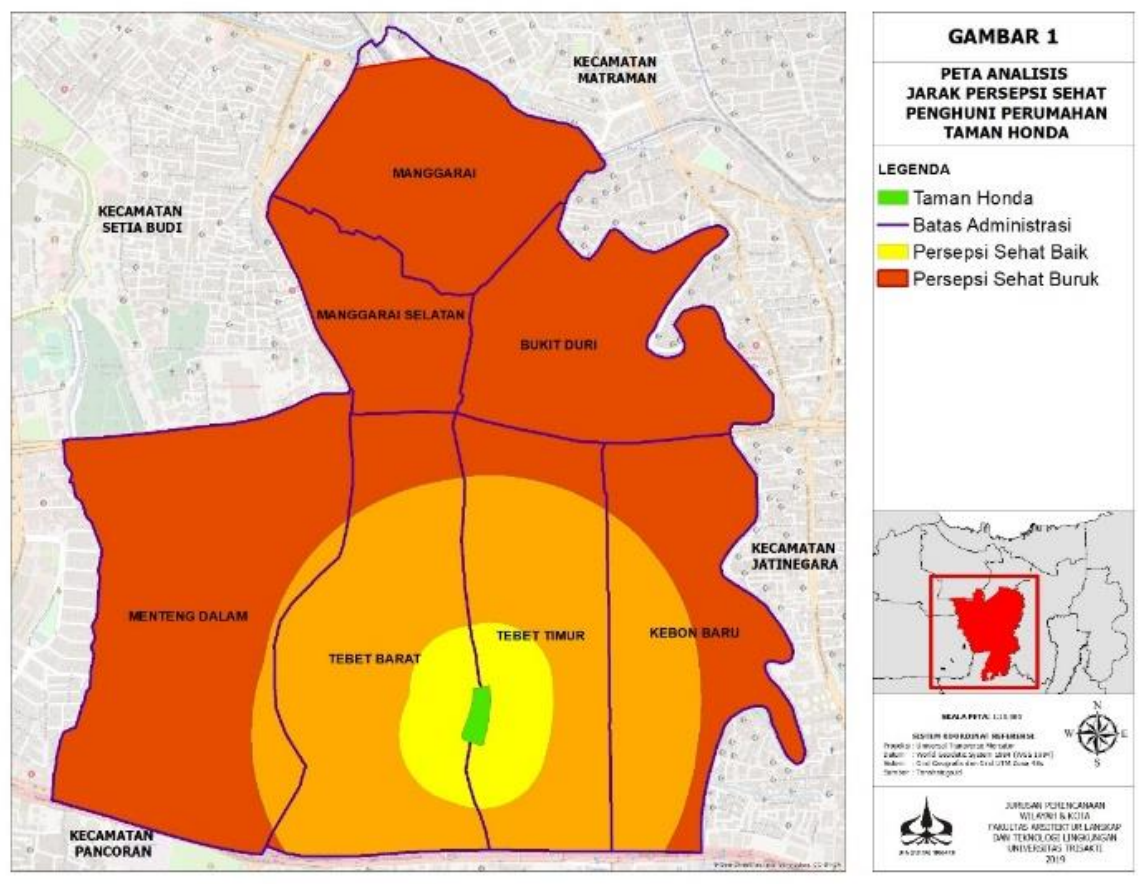

Gambar 4. Peta Analisis Jarak Terhadap Persepsi Sehat Penghuni Perumahan

\section{Sosio-demografi terhadap Persepsi Sehat}

Faktor sosio-demografi mempengaruhi persepsi sehat penghuni perumahan dilihat dari usia, jenis kelamin, dan status pekerjaan penghuni perumahan. Ketiga faktor ini dijabarkan secara detil melalui analisis tabulasi.

Usia memiliki nilai koefisien negatif sebesar $(-1,910)$, artinya terjadi hubungan negatif antara usia dengan persepsi sehat. Semakin tinggi usia maka semakin turun persepsi sehat penghuni perumahan.

Tabel 4. Tabulasi Silang Usia dengan Persepsi Sehat

\begin{tabular}{lcc}
\hline \multirow{2}{*}{ Usia } & \multicolumn{2}{c}{ Persepsi Sehat } \\
\cline { 2 - 3 } & Baik & Buruk \\
\hline Remaja & $\mathbf{2 6 . 0}$ & 14.6 \\
Dewasa & 8.3 & 24.0 \\
Lansia & $\mathbf{1 6 . 7}$ & 10.4 \\
Total & 51.0 & 49.0 \\
\hline
\end{tabular}

Berdasarkan Tabel 4 dapat diketahui bahwa golongan usia remaja dan lansia memiliki persepsi sehat yang baik dikarenakan mereka lebih merasakan manfaat yang didapatkan dari keberadaan Taman Honda. Hasil ini sejalan dengan hasil penelitian milik Maas et al. (2006) yang menyatakan bahwa kelompok usia yang memiliki persepsi sehat baik pada area yang lebih hijau, di mana penelitian tersebut menghasilkan bahwa kelompok usia remaja dan lansia lebih banyak mendapatkan manfaat dengan adanya RTH.
Tabel 5. Tabulasi Silang Jenis Kelamin dengan Persepsi Sehat

\begin{tabular}{lcc}
\hline \multirow{2}{*}{ Jenis Kelamin } & \multicolumn{2}{c}{ Persepsi Sehat } \\
\cline { 2 - 3 } & Baik & Buruk \\
\hline Laki-laki & 35.4 & 9.4 \\
\hline Perempuan & 15.6 & $\mathbf{3 9 . 6}$ \\
\hline Total & 51.0 & 49.0 \\
\hline
\end{tabular}

Berdasarkan Tabel 5 dapat diketahui korelasi jenis kelamin terhadap persepsi sehat, menghasilkan bahwa perempuan memiliki persepsi sehat yang buruk dibandingkan dengan laki-laki. Hal ini sejalan dengan hasil penelitian Idler dalam Kusumadewi (2014) yang mengamati kesenjangan antara persepsi sehat dengan risiko kematian berdasarkan jenis kelamin yang menghasilkan bahwa perempuan lebih sering melaporkan kondisi kesehatan yang lebih buruk dibandingkan dengan laki-laki.

Tabel 6. Tabulasi Silang Pekerjaan dengan Persepsi Sehat

\begin{tabular}{llc}
\hline \multirow{2}{*}{ Status Pekerjaan } & \multicolumn{2}{c}{ Persepsi Sehat } \\
\cline { 2 - 3 } & Baik & Buruk \\
\hline Tidak Bekerja & $\mathbf{3 3 . 3}$ & 13.5 \\
\hline Bekerja & 17.7 & $\mathbf{3 4 . 4}$ \\
\hline Total & 51.0 & 49.0 \\
\hline
\end{tabular}


Pekerjaan terhadap persepsi sehat, terdapat pengaruh yang signifikan. Pekerjaan memiliki nilai koefisien negatif sebesar (-6.463), artinya terjadi hubungan negatif antara pekerjaan dengan persepsi sehat. Dalam hal status pekerjaan dapat disimpulkan bahwa orang yang tidak bekerja memiliki persepsi sehat yang baik dibandingkan dengan orang yang bekerja, hal ini disebabkan karena seseorang yang tidak bekerja cenderung memiliki waktu luang yang relatif lebih banyak dibandingkan orang yang bekerja, dan orang yang tidak bekerja ini mereka menggunakan waktu luang tersebut untuk berkunjung ke Taman Honda untuk melakukan berbagai macam kegiatan. Hasil ini sejalan dengan Kusumadewi (2014) yang menghasilkan bahwa adanya hubungan antara status pekerjaan dengan persepsi sehat.

\section{Sosio-demografi terhadap Jarak}

Terdapat faktor jarak dan sosio-demografi (usia, jenis kelamin, pekerjaan) penghuni perumahan Kecamatan Tebet untuk mengetahui frekuensi persebaran penghuni perumahan berdasarkan tempat tinggal mereka. Untuk lebih jelasnya dapat dilihat pada Tabel 7.

Tabel 7. Analisis Sosio-demografi terhadap Jarak

\begin{tabular}{|c|c|c|c|}
\hline & \multicolumn{3}{|c|}{ Persepsi Sehat Baik } \\
\hline Row Labels & $>300 \mathrm{~m}$ & $300 m-1000 m$ & $1 \mathrm{~km}-3 \mathrm{~km}$ \\
\hline Laki-laki & 13 & 14 & 7 \\
\hline Remaja & 4 & 6 & 6 \\
\hline Bekerja & 1 & 3 & 2 \\
\hline $\begin{array}{l}\text { Tidak } \\
\text { Bekerja }\end{array}$ & 3 & 3 & 4 \\
\hline Dewasa & 3 & 2 & \\
\hline Bekerja & 2 & 2 & \\
\hline $\begin{array}{l}\text { Tidak } \\
\text { Bekerja }\end{array}$ & 1 & & \\
\hline Lansia & 6 & 6 & 1 \\
\hline Bekerja & 1 & 2 & 1 \\
\hline $\begin{array}{l}\text { Tidak } \\
\text { Bekerja }\end{array}$ & 5 & 4 & \\
\hline Perempuan & 6 & 5 & 4 \\
\hline Remaja & 2 & 4 & 3 \\
\hline Bekerja & 1 & 1 & \\
\hline $\begin{array}{l}\text { Tidak } \\
\text { Bekerja }\end{array}$ & 1 & 3 & 3 \\
\hline Dewasa & 1 & 1 & 1 \\
\hline Bekerja & 1 & & \\
\hline $\begin{array}{l}\text { Tidak } \\
\text { Bekerja }\end{array}$ & & 1 & 1 \\
\hline Lansia & 3 & & \\
\hline Bekerja & & & \\
\hline $\begin{array}{l}\text { Tidak } \\
\text { Bekerja }\end{array}$ & 3 & & \\
\hline Total & 19 & 19 & 11 \\
\hline
\end{tabular}

Berdasarkan tabel di atas dapat diketahui, pada jarak $>300$ $\mathrm{m}$ laki-laki kelompok usia lansia yang tidak bekerja memiliki persepsi sehat yang baik. Pada jarak 300-1000 m, laki-laki kelompok usia lansia dan remaja memiliki frekuensi yang sama. Kelompok lansia yang tidak bekerja sedikit lebih banyak dibandingkan kelompok usia remaja akan tetapi remaja yang bekerja sedikit lebih banyak dibandingkan dengan lansia. Pada jarak 1-3 km laki-laki dengan kelompok usia remaja yang tidak bekerja memiliki persepsi sehat yang baik dan terlihat lebih mendominasi.

\section{SIMPULAN}

Ada korelasi dan pengaruh ruang terbuka hijau terhadap persepsi sehat. Persepsi sehat penghuni perumahan semakin menurun seiring bertambahnya jarak penghuni perumahan. Terdapat hubungan antara sosio-demografi penghuni perumahan dengan persepsi sehat. Laki-laki dengan kelompok usia remaja dan lansia dan tidak bekerja memiliki persepsi sehat yang baik dikarenakan memiliki waktu luang yang relatif lebih banyak.

\section{DAFTAR PUSTAKA}

Ekkel, E.D., and de Vries, S. 2017. Nearby green space and human health: Evaluating accessibility metrics. Landscape and urban planning, 157, 214-220.

Jesica, J., Kaswanto, R.L., and Arifin, H.S. 2019. Management of "Pekarangan" in Informal Settlement of Ciliwung River Riparian Landscape. KnE Social Sciences, 3(21):4984

Kabisch, N., Qureshi, S., and Haase, D. 2015. Humanenvironment interactions in urban green spaces $-A$ systematic review of contemporary issues and prospects for future research. Environmental Impact Assessment Review, 50, 25-34.

Kusumadewi, C.A. 2014. Hubungan ruang terbuka hijau (RTH) dengan persepsi sehat masyarakat di Kecamatan Jati Asih Kota Bekasi tahun 2014.

Lee, A.C., and Maheswaran, R. 2011. The health benefits of urban green spaces: a review of the evidence. Journal of public health, 33(2), 212-222.

Maas, J., Verheij, R.A., Groenewegen, P.P., De Vries, S., and Spreeuwenberg, P. 2006. Green space, urbanity, and health: how strong is the relation? Journal of Epidemiology \& Community Health, 60(7), 587592.

Nutsford, D., Pearson, A.L., and Kingham, S. 2013. An ecological study investigating the association between access to urban green space and mental health. Public health, 127(11), 1005-1011.

Stigsdotter, U.K., Ekholm, O., Schipperijn, J., Toftager, M., Kamper-Jørgensen, F., and Randrup, T.B. 2010. Health promoting outdoor environments-Associations between green space, and health, health-related quality of life and stress based on a Danish national representative survey. Scandinavian journal of public health, 38(4), 411-417.

Suminah, N., Sulistyantara, B., dan Budiarti, T. 2017. Studi Persepsi dan Preferensi Penghuni Terhadap Ruang Hijau di Rumah Susun Sederhana Sewa Provinsi DKI Jakarta serta Strategi Perbaikannya. Jurnal Lanskap Indonesia, 9(1), 36-51. 